\title{
A survey of Transcaucasian Dipoena sensu lato (Aranei: Theridiidae) with a description of new species
}

\author{
Обзор закавказских Dipoena sensu lato (Aranei: Theridiidae), \\ с описанием нового вида
}

\author{
Mykola M. Kovblyuk ${ }^{1,5}$, Yuri M. Marusik ${ }^{2,5}$ \& Mikhail M. Omelko ${ }^{3,45}$ \\ Н.М. Ковблюк ${ }^{1,5}$, Ю.М. Марусик ${ }^{2,5}$, М.М. Омелько ${ }^{3,4,5}$ \\ ${ }^{1}$ Zoology Department, V.I. Vernadsky Taurida National University, Yaltinskaya Street 4, Simferopol 95007, Ukraine. E-mail: \\ kovblyuk@mail.ru \\ ${ }^{2}$ Institute for Biological Problems of the North, RAS, Portovaya Str. 18, Magadan 685000, Russia. E-mail: yurmar@mail.ru \\ ${ }^{3}$ Gornotaezhnaya Station FEB RAS, Gornotaezhnoe Vil., Ussuriyski Dist., Primorski krai 692533, Russia. E-mail: omelkom@gmail.com \\ ${ }^{4}$ Far Eastern Federal University, Sukhanova 8, Vladivostok 690950, Russia. \\ ${ }^{5}$ Zoological Museum, University of Turku, FI-20014, Turku, Finland. \\ ${ }^{1}$ Кафедра зоологии, Таврический национальный университет им. В.И.Вернадского, ул. Ялтинская 4, Симферополь 95007 , \\ Украина. \\ ${ }^{2}$ ИБПС ДВО РАН, Портовая 18, Магадан 685000. \\ ${ }^{3}$ Горнотаёжная станция ДВО РАН, с. Горнотаёжное, Уссурийский район, Приморский край 692533, Россия. \\ ${ }^{4}$ Дальневосточный федеральный университет, ул. Суханова 8, Владивосток 690950, Россия. \\ 5 Зоологический музей, Университет Турку, FI-20014, Финляндия.
}

KEY WORDS: Abkhazia, Georgia, Azerbaijan, new species.

КЛЮЧЕВЫЕ СЛОВА: Абхазия, Грузия, Азербайджан, новый вид.

ABSTRACT. Seven species of Dipoena sensu lato belonging to four genera: Dipoena Thorell, 1869 (2 species), Lasaeola Simon, 1881 (3 species), Phycosoma O. Pickard-Cambridge, 1879 (1 species) and Yaginumena Yoshida, 2002 (1 species) were found in Transcaucasia. One new species, Lasaeola dbari sp.n. is described from Abkhazia. Lasaeola tristis (Hahn, 1833) is recorded from Caucasus for the first time.

РЕЗЮМЕ. Семь видов Dipoena sensu lato из четырёх родов обнаружены в Закавказье: Dipoena Thorell, 1869 (2 вида), Lasaeola Simon, 1881 (3 вида), Phycosoma O. Pickard-Cambridge, 1879 (1 вид) и Yaginumena Yoshida, 2002 (1 вид). Один новый вид Lasaeola dbari sp.n. описан из Абхазии. Lasaeola tristis (Hahn, 1833) отмечен на Кавказе впервые.

\section{Introduction}

Dipoena Thorell, 1869 is one of the largest genera in Theridiidae. Currently it includes 155 extant species [Platnick, 2012] distributed all over the globe, although most of the known species are restricted to the Holarctic. Until recently this genus encompassed several dozen more species until Wunderlich [1988] revalidated Lasaeola Simon, 1881 and removed several species to the new genus Dipoenata Wunderlich, 1988. Three species were transferred from Dipoena to Yaginumena
Yoshida, 2002. Later Fitzgerald \& Sirvid [2003] revalidated Phycosoma O. Pickard-Cambridge, 1879 though to be a synonym of Euryopis Menge, 1868, and transferred some Dipoena into this genus.

The taxonomic limits of Dipoena and the revalidated or recently described new genera are not very clear [cf. Wunderlich, 2008: 285-286]. None of them have clear diagnostic characters. Species previously considered in Dipoena sensu lato are relatively poorly studied in the former Soviet Union and particularly in the Caucasus. Only six species belonging to this group are known from Caucasus (North Caucasus, Armenia, Azerbaijan and Georgia). The first species, Dipoena melanogaster (C.L. Koch, 1837) was reported as recently as 1997 from Georgia [Mkheidze, 1997]. Dipoena nigroreticulata (Simon, 1879) was recorded from Azerbaijan by Guseinov [2002]. Phycosoma inornatum (O.Pickard-Cambridge, 1861 ) and Lasaeola prona (Menge, 1868) were reported from Azerbaijan by Marusik et al. [2005a]. At the same time Yaginumena maculosa (Yoshida et Ono, 2000) was recorded from several localities in East and West Caucasus [Marusik et al., 2005b]. The fifth species Dipoena braccata (C.L. Koch, 1841), was reported by Ponomarev \& Mikhailov [2007] from North Caucasus.

While studying Theridiidae of Caucasus we found one species new to Caucasus and one species new to science, which seems to belong to Lasaeola. It has an unusual abdominal pattern and an extremely long embo- 

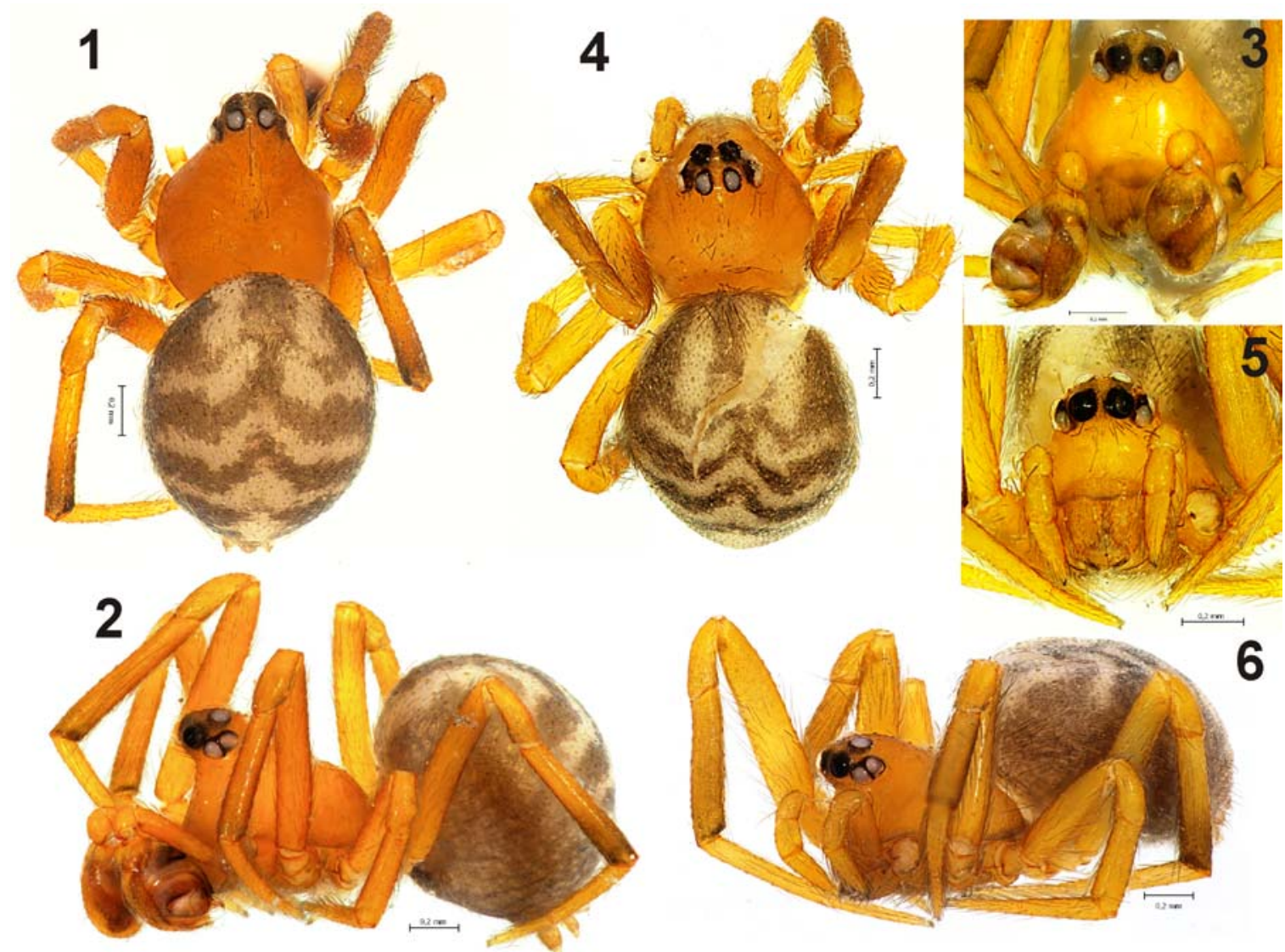

Figs 1-6. Habitus of Lasaeola dbari sp.n.: 1-3 - male, dorsal, lateral and frontal, respectively; 4-6 - female, dorsal, frontal and lateral, respectively. Scale $0.2 \mathrm{~mm}$.

Рис. 1-6. Габитус Lasaeola dbari sp.n.: 1-3 - самец, дорсально, латерально и фронтально, соответственно; 4-6 - самка, дорсально, фронтально и латерально, соответственно. Масштаб 0,2 мм.

lus and insemination ducts. In this the new species is described alongside a brief survey of Dipoena sensu lato species in the Caucasus.

\section{Material and methods}

Specimens were photographed using either a JEOL JSM-5200 scanning electron microscope or an Olympus Camedia E-520 camera attached to an Olympus SZX16 stereomicroscope at the Zoological Museum, University of Turku. Digital images were montaged using "CombineZM" image stacking software. Photographs were taken in dishes of different sizes with paraffin at the bottom. Different sized holes were made in the bottom to keep the specimens in the correct position. Figures had been made previously and in some cases we were unable to generate scale bars for the digital photographs. All measurements are given in mm. Drawings we made either by using a grid method with a MBS-9 stereomicroscope or a Leitz stereomicroscope with a camera lucida. The bleached epigyne of the holotype female was temporarily coloured with Chlorazol Black. The epigyne was macerated using $\mathrm{KOH}$ solution.
Acronyms: IZA — Institute of Zoology, Baku, Azerbaijan; TNU - Zoology Department, Taurida National University, Simferopol, Ukraine; ZMMU — Zoological Museum of the Moscow State University, Russia; ZMUT - Zoological Museum, University of Turku, Finland; EFH - E.F. Huseynov; YMM - Yu.M. Marusik.

\section{Taxonomic survey}

\section{Lasaeola dbari sp.n.}

Figs 1-18.

MATERIAL. Holotype $\sigma^{7}$ (ZMMU) and paratype $\odot$ (ZMMU), ABKHAZIA, Gudauta District, Myusser Part of Pitsunda-Myusser Reserve, $43^{\circ} 10^{\prime} \mathrm{N}, 40^{\circ} 25^{\prime} \mathrm{E}, 23 \mathrm{~m}$, moist canyon, 15-24.07.2009 (M.M. Kovblyuk \& N.N. Yunakov). Paratype: $10^{7}$ (ZMMU), Abkhazia, environs of Kelasur, clay shadowed cliffs, $42^{\circ} 58^{\prime} \mathrm{N}$ 41 $04^{\prime} \mathrm{E}, 11.10 .2004$ (YMM).

ETYMOLOGY. The species name is a patronym honouring our colleague Dr. Roman S. Dbar, head of the State Ecological Service in Abkhazia, who helped to arrange the expedition of MK to Abkhazia.

DIAGNOSIS. The new species can be easily recognized by its characteristic pattern of transverse stripes, 

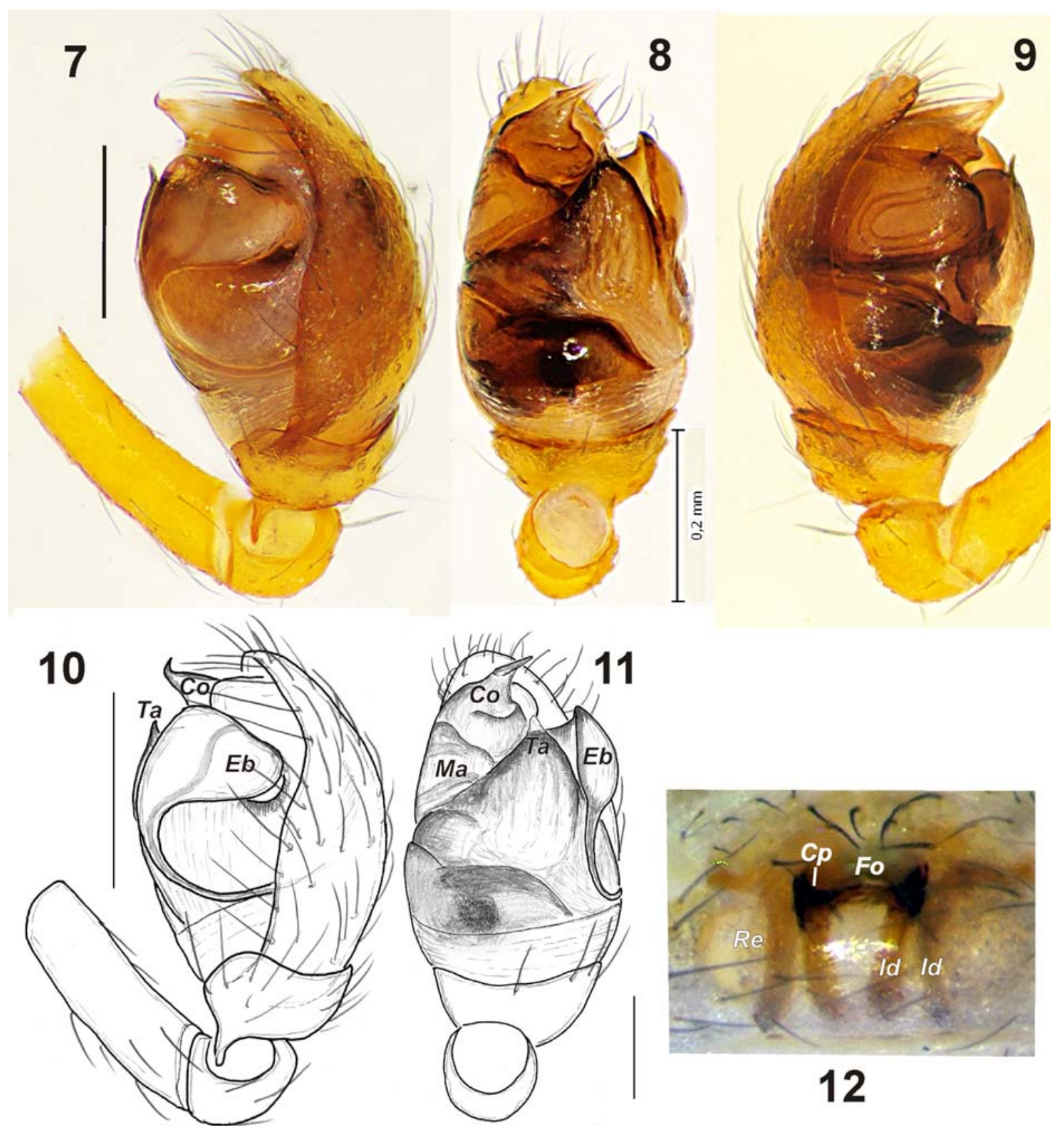

12

Figs 7-12. Male palp and epigyne of Lasaeola dbari sp.n.: 7, 10 - male palp, retrolateral; 8, 11 - male palp, ventral; 9 - male palp, prolateral; 12 - epigyne, ventral. Scale $0.2 \mathrm{~mm}$. Abbreviations: $C o$ - conductor; $C p$ - copulatory opening; $E b$ - base of embolus; $F o-$ fovea; $I d$ - insemination duct; $M a$ - median apophysis; $T a$ - tegular apophysis.

Рис. 7-12. Пальпа самца и эпигина Lasaeola dbari sp.n.: 7, 10 - пальпа самца, ретролатерально; 8, 11 - пальпа самца, вентрально; 9 - пальпа самца, пролатерально; 12 - эпигина, вентрально. Масштаб 0,2 мм. Обозначения: Сo - кондуктор; $C p-$ копулятивное отверстие; $E b$ - основание эмболюса; $F o$ - ямка эпигины; $I d-$ осеменительный (копулятивный) канал; $M a-$ медиальный отросток; $T a$ - тегулярный отросток.

unusual for Lasaeola species. L. dbari sp.n. can be distinguished by the structure of the copulatory organs. Males have a very long embolus, unknown in other congeners. The base $(E b)$ and beginning of the embolus are clearly visible. Females of the new species appear to have the longest insemination ducts among all Lasaeola and members of related genera.
COMMENTS. We placed the new species into $\mathrm{La}$ saeola because of some similarity in the epigyne of $L$. dbari sp.n. with that of the type species L. prona (Menge, 1868).

DESCRIPTION. Male/female. Total length 1.88/1.80. Carapace: $0.85 / 0.77$ long, $0.72 / 0.70$ wide, $0.6 / 0.42$ high. Abdomen: 1.12/1.20 long, 1.0/1.0 wide. Eyes (after larg- 

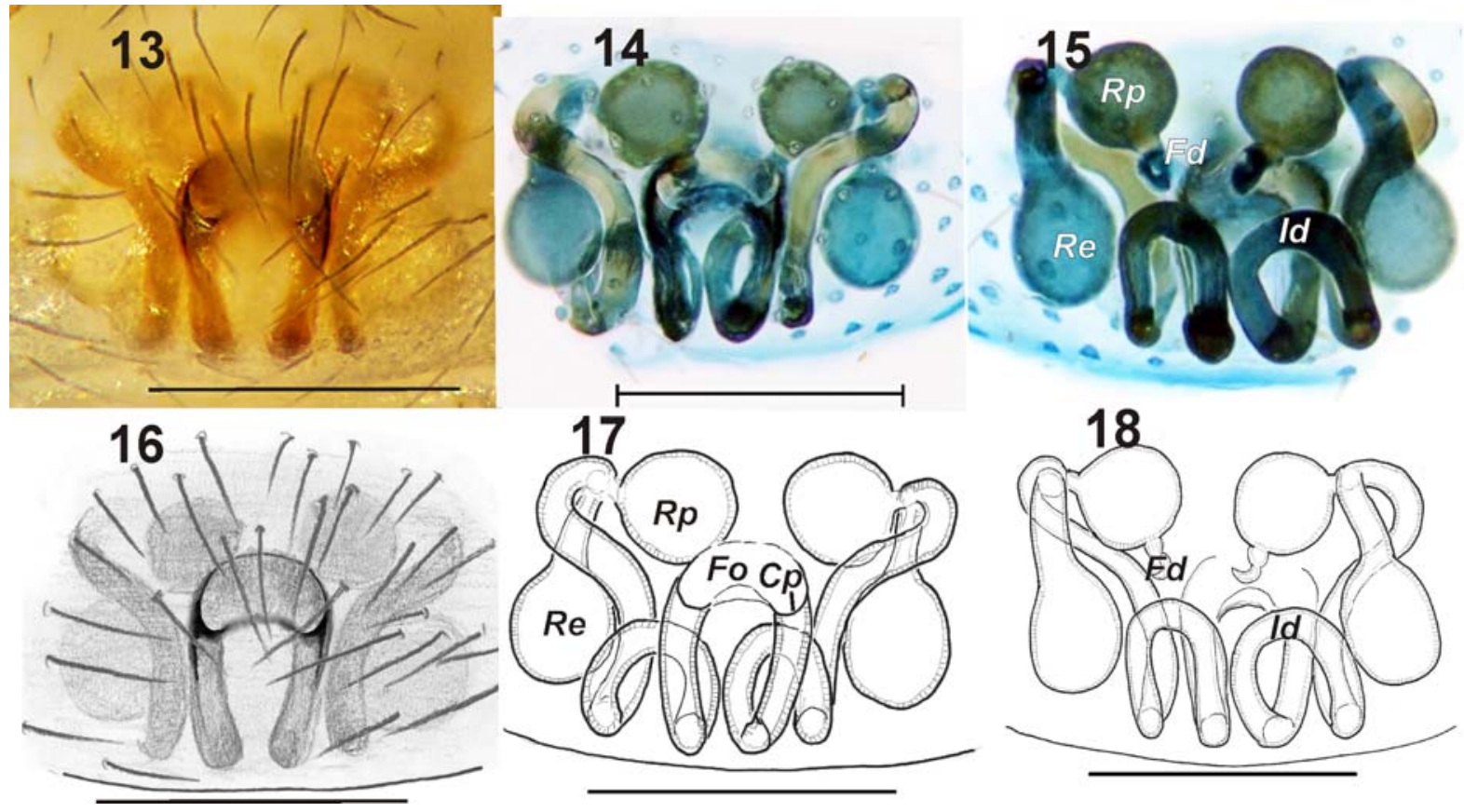

Figs 13-18. Epigyne of Lasaeola dbari sp.n.: 13-14, 16-17 - ventral; 15, 18 - dorsal. 14-15, 17-18 - after maceration. Scale 0.2 mm. Abbreviations: $C p$ - copulatory opening; $F d$ - fertilization duct; $F o$ - fovea; $I d-$ insemination duct; $R e$ - accessorial receptaculum, $R p$ - proper receptaculum.

Рис. 13-18. Эпигина Lasaeola dbari sp.n.: 13-14, 16-17 - вентрально; 15, 18 - дорсально. 14-15, 17-18 - после мацерации. Масштаб 0,2 мм. Обозначения: $C p-$ копулятивное отверстие; $F d$ - оплодотворительный канал; $F o-$ ямка эпигины; $I d-$ осеменительный (копулятивный) канал; $R e$ - дополнительная рецептакула, $R p$ - настоящая рецептакула.

est diameter): AM 0.098/0.07; AL 0.084/0.07; PM 0.098/ 0.098; PL 0.084/0.084. Eyes interdistances: AM-AM 0.07/ 0.098; AM-AL 0.014/0.028; PM-PM 0.056/0.056; PMPL 0.056/0.042; AM-PM 0.07/0.07; AL-PL 0/0; AMclypeus 0.378/0.252; AL-clypeus 0.364/0.28.

Habitus and pattern as in Figs 1-6. General coloration is yellow. Tibia I and IV slightly darkened distally. Abdomen is grey with two white median bands and four pairs of white stripes. Leg podomere lengths $\left(\sigma^{\gamma} / q\right)$

\begin{tabular}{|l|l|l|l|l|l|l|}
\hline & femur & patella & tibia & metatarsus & tarsus & Total \\
\hline I & $0.90 / 0.85$ & $0.33 / 0.35$ & $0.70 / 0.60$ & $0.68 / 0.6$ & $0.38 / 0.40$ & $2.98 / 2.80$ \\
\hline II & $0.88 / 0.75$ & $0.33 / 0.33$ & $0.58 / 0.45$ & $0.55 / 0.425$ & $0.38 / 0.35$ & $2.70 / 2.30$ \\
\hline III & $0.63 / 0.55$ & $0.25 / 0.30$ & $0.43 / 0.40$ & $0.43 / 0.4$ & $0.35 / 0.35$ & $2.08 / 2.00$ \\
\hline IV & $0.88 / 0.80$ & $0.33 / 0.35$ & $0.63 / 0.60$ & $0.65 / 0.63$ & $0.38 / 0.35$ & $2.85 / 2.73$ \\
\hline
\end{tabular}

Male palp as in Figs 7-11. Tegular apophysis (Ta) triangle-shaped in ventral view with a pointed tip; conductor $(\mathrm{Co})$ elongate, sharply pointed; embolus long and thin with a massive base $(E b)$.

Epigyne as in Figs 12-18, with bean shaped fovea $(F o)$, long insemination ducts $(I d)$ and two pairs of receptacula ( $R e$ and $R p$ ) subequal in size. Proper receptacula $(R p)$ round with short converging fertilization ducts $(F d)$. Accessorial receptacula $(R e)$ droplet shaped.

DISTRIBUTION. Known only from the type locality.

\section{Lasaeola prona (Menge, 1868)}

Figs 19-22.

Dipoena p.: Miller, 1967: 290, pl. XIII, f. 16-19 (ठㅇ). Dipoena p.: Roberts, 1985: 176, f. $78 \mathrm{~b}\left(\sigma^{7}+\right)$.
Dipoena p.: Roberts, 1995: 269, f. ( (

Dipoena p.: Roberts, 1998: 284, f. (ठ우).

Dipoena p.: Paquin \& Dupérré, 2003: 215, f. 2402-2404 ( $\sigma^{7}$ ) $)$. For complete list of references see Platnick [2012].

MATERIAL EXAMINED: AZERBAIJAN: $2 \sigma^{\top} \sigma^{\top}, 4$ 우 (ZMMU), NE part of Naxçývan, Shakhbuz Dist., Batabat locality, $39^{\circ} 31,9^{\prime} \mathrm{N} 45^{\circ} 47.3^{\prime} \mathrm{E}, 2100 \mathrm{~m}$, subalpine meadows \& under stones, 3.06.2003 (YMM).

CAUCASIAN RECORDS. This species has been reported from Naxçývan only [Marusik et al., 2005a].

COMMENTS. This species is properly described in the above-mentioned papers. Specimens from Finland and Naxçývan have a slightly different median apophysis.

DISTRIBUTION. This species has a Holarctic range.

Lasaeola tristis (Hahn, 1833) Figs 23-26.

Dipoena t.: Miller, 1967: 289, pl. XIII, f. 1-4 ( $\left.\sigma^{7}+\right)$.

Dipoena t.: Roberts, 1995: 269, f. ( $\left(\sigma^{7}+\right)$.

Dipoena $t$ : Roberts, 1998: 284, f. ( $\sigma^{7}+$ ).

L. $t$ : : Knoflach \& Pfaller, 2004: 137, f. $20 \mathrm{f}\left(\sigma^{7}\right)$.

For complete list of references see Platnick [2012].

MATERIAL EXAMINED: AZERBAIJAN: 1 \%, 14 우 (ZMMU), SE Azerbaijan, Lenkoran District, environs of Aurora Vill., 3840’N 4852'E, 23-28.04.2001 (YMM).

COMMENTS. The species is well described in the above-mentioned papers. Here we provide SEM figures of the palp. Caucasian specimens have no differences with those from Finland. 

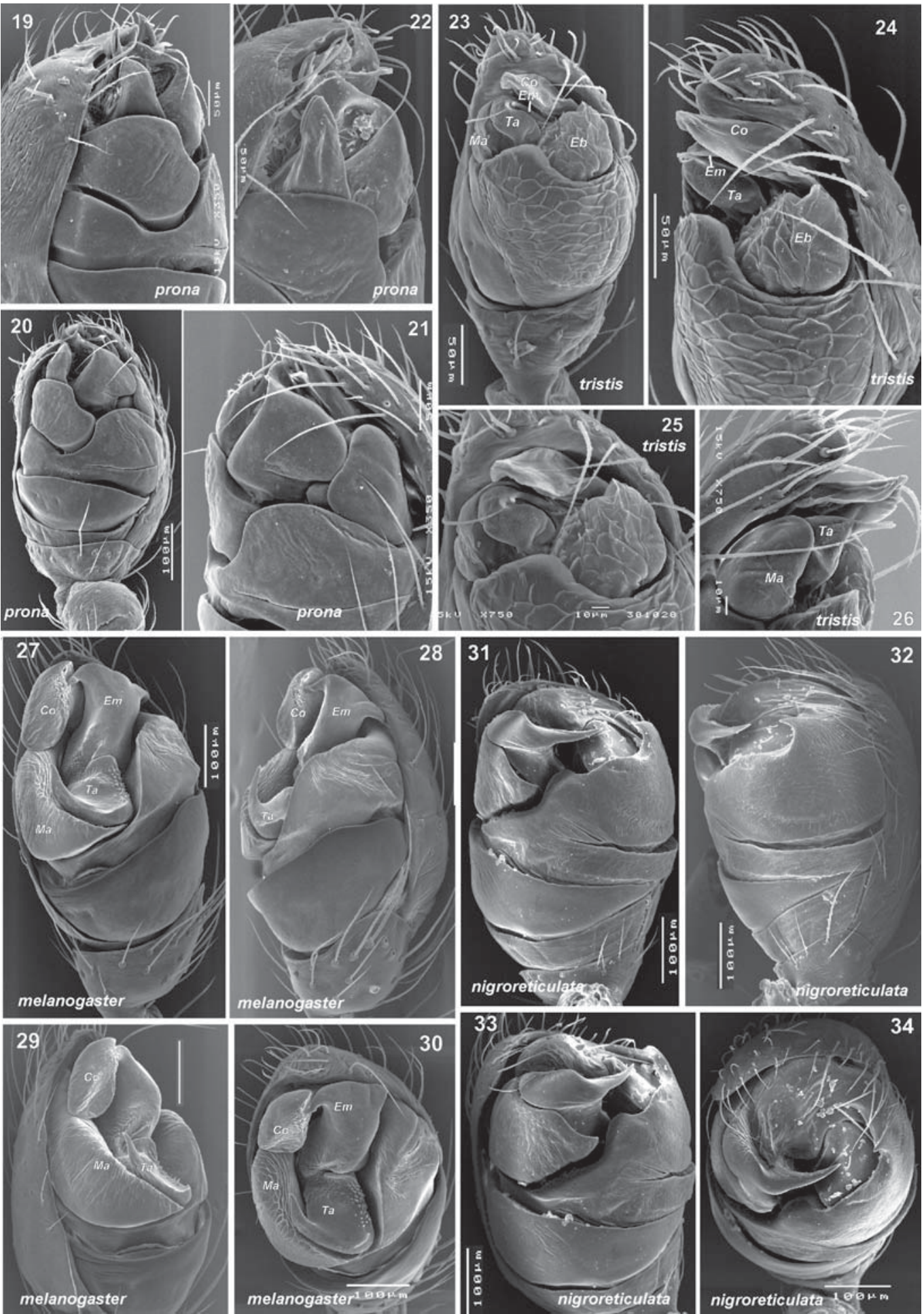

Figs 19-34. Male palps of Lasaeola prona (19-22), L. tristis (23-26), Dipoena melanogaster (27-30) and D. nigroreticulata (3134): $19,26,29,33$ - prolateral; 20, 23, 27, 31 - ventral; 21, 24, 28, 32 - retrolateral; 22 - prolateral-anterior; 25 - ventro-anterior; 30, 34 - anterior. 19-22 - from Naxcývan (Azerbaijan); 22-30 - from Lenkoran (Azerbaijan); 31-34 — from Baku (Azerbaijan). Abbreviations: $\mathrm{Co}$ - conductor; $E b$ - base of embolus; $E m$ - embolus; $M a$ - median apophysis; $T a$ - tegular apophysis.

Рис. 19-34. Пальпы самцов Lasaeola prona (19-22), L. tristis (23-26), Dipoena melanogaster (27-30) и D. nigroreticulata (3134): 19, 26, 29, 33 - пролатерально; 20, 23, 27, 31 - вентрально; 21, 24, 28, 32 - ретролатерально; 22 - пролатерально-спереди; 25 - вентрально-спереди; 30, 34 - спереди. 19-22 - из Нахичевани (Азербайджан); 22-30 - из Ленкорани (Азербайджан); 3134 - из Баку (Азербайджан). Обозначения: $C o-$ кондуктор; $E b$ - основание эмболюса; $E m$ - эмболюс; $M a-$ медиальный отросток; $\mathrm{Ta}$ - тегулярный отросток. 


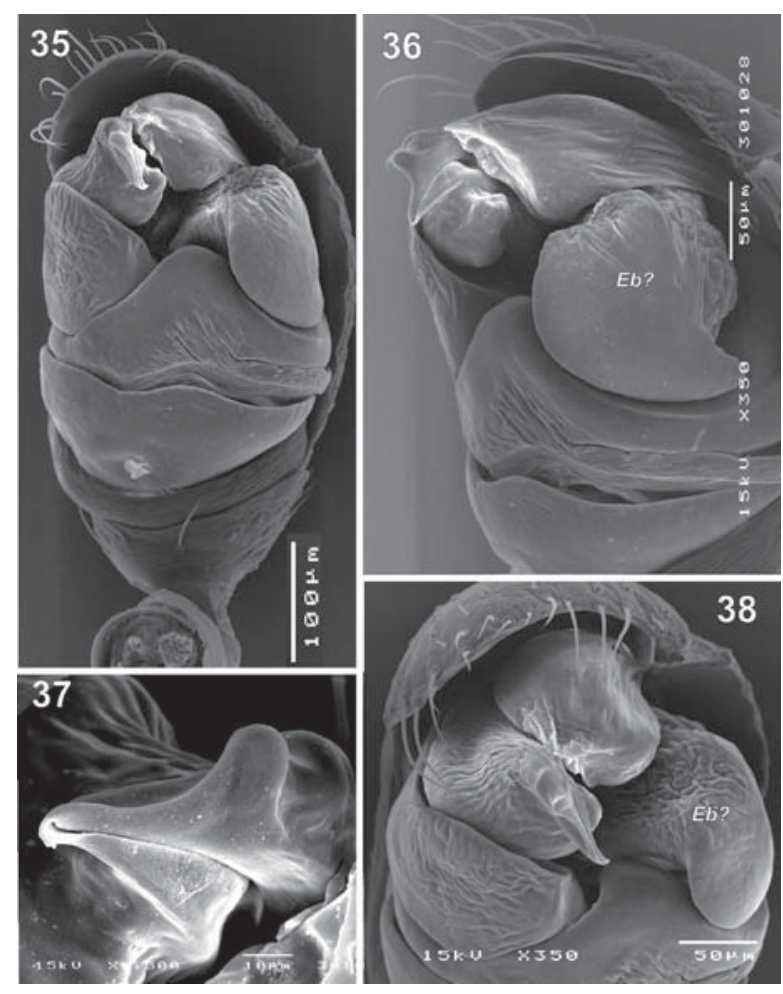

Figs 35-38. Male palp of Phycosoma inornatum from Finland: 35 - ventral; 36 - retrolateral; 37 - conductor; 38 - anterior Abbreviations: $E b$ ? — base of embolus.

Рис. 35-38. Пальпа самца Phycosoma inornatum из Финляндии: 35 - вентрально; 36 - ретролатерально; 37 - кондуктор; 38 - спереди. Обозначения: $E b$ ? - основание эмболюса.

DISTRIBUTION. This species is distributed from Western Europe to Altai, south to the Mediterranean and Tajikistan. The record from Azerbaijan is the first for the entire Caucasus.

Dipoena melanogaster (C.L. Koch, 1837) Figs 27-30.

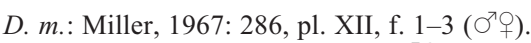

D. $m$ : : Roberts, 1985: 176, f. $78 \mathrm{f}\left(\sigma^{7}+\right)$.

D. $m$ : : Roberts, 1995: 270, f. $\left(\sigma^{7}+\right)$.

D. $m$.: Roberts, 1998: 285, f. ( $\left.\sigma^{7}+\right)$.

For complete list of references see Platnick [2012].

MATERIAL EXAMINED: AZERBAIJAN: $1 \sigma^{7}$ (IZA), CN Azerbaijan, Khyzy Dist., env. of Yarymja Vill., 6.06.2000 (EFG);1 o (IZA), N Azerbaijan, Ismailly Dist., Ismailly Reserve, $1200 \mathrm{~m}$, 11.07.2001 (EFG); 1 juv. [a05] SE Azerbaijan, Lenkoran Dist., env. of Aurora Vil., 38 40’N 48 52'E, 23-28.04.2001 (YMM); 1 $\sigma^{7}$ (IZA), SE Azerbaijan, Lenkoran Dist., env. of Apo Vill., 28.05.2003 (EFG).

CAUCASIAN RECORDS. Khosta (Krasnodar Area, Russia), Abkhazia, Central and West Georgia [Otto \& Tramp, 2011] and Azerbaijan [Dunin, 1989].

COMMENTS. This species is well described in several of the papers mentioned above.

DISTRIBUTION. This species is restricted to the West Palaearctic and known from Western Europe to Azerbaijan.
Dipoena nigroreticulata (Simon, 1879)

Figs 31-34.

D. n.: Miller, 1967: 287, pl. XII, f. 4-9 (O'O).

D. $n$.: Finch, 1999: 66, f. 1a-b ( $\left.\sigma^{7}+\right)$.

For complete list of references see Platnick [2012].

MATERIAL EXAMINED: AZERBAIJAN: $1 \sigma^{7}$ (IZA) Absheron Peninsula, Baku, Institute of Zoology garden, 11.09.2001 (EFG).

CAUCASIAN RECORDS. Absheron Peninsula [Guseinov, 2002].

COMMENTS. Here we provide the first SEM figures of the male palp because this species is rather poorly known. The structure of the male palp is rather different from that seen in D. melanogaster (Figs 2730), the type species of the genus.

DISTRIBUTION. The species is known from Portugal to Poland [Helsdingen, 2010] and from Azerbaijan. 1861)

Phycosoma inornatum (O. Pickard-Cambridge,

Figs $35-38$.

Dipoena inornata: Wiehle, 1937: 187, f. 186-189 (○ㅇ).

Dipoena inornata: Roberts, 1985: 176, f. 78c (ठㅇ)

Dipoena inornata: Roberts, 1995: 268, f. $\left(\bigcirc^{\top}\right.$ )

Dipoena inornata: Roberts, 1998: 283, f. ( $\left.\sigma^{\top}+\right)$.

For complete list of references see Platnick [2012].

MATERIAL EXAMINED: AZERBAIJAN: 1 (ZMMU),

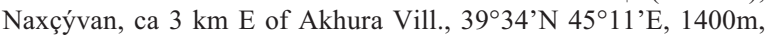
2.06.2003 (YMM).

CAUCASIAN RECORDS. Within the Caucasus this species has been recorded from Naxçývan only [Marusik et al., 2005a].

COMMENTS. This species is well described in the above-mentioned papers. Here we provide figures of the male palp made from Finnish specimens.

DISTRIBUTION. This species is restricted to the West Palaearctic and known from Western Europe to Azerbaijan.

Yaginumena maculosa (Yoshida et Ono, 2000) Figs 39-42.

Dipoena $m$. Yoshida \& Ono, 2000: 147, f. 37-39 $\left(\sigma^{7}\right)$.

Y. m.: Yoshida, 2003: 169, f. 462-465, $593\left(\sigma^{7}\right)$.

Y. m.: Marusik et al., 2005b: 125, f. 1-12 (О'O).

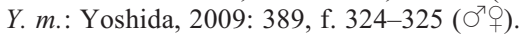

MATERIAL EXAMINED: AZERBAIJAN: $4 \sigma^{7}, 5$ oq (ZMMU), Lenkoran Distr., environs of Aurora Vill., $38^{\circ} 41^{\prime} \mathrm{N}$ 48 17'E, 36 m, 21-29.05.2003 (YMM); 1 ㅇ (ZMMU), Lenkoran Distr., Hyrcan Reserve, 38³8,5’N 4847,5’'E, 23.05.2003 (YMM); 2 우 (ZMMU), Absheron Peninsula, env. of Baku, Mardakyan, $40^{\circ}$

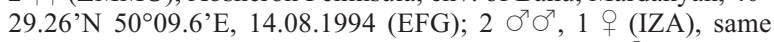
locality, 27.06.1996 (EFG). ABKHAZIA: 1 subad. + (ZMMU), environs of Pitsunda, Ldzaa Vill., Pinus pityusa along seashore, litter, $43^{\circ} 10.255^{\prime} \mathrm{N}, 40^{\circ} 22.370^{\prime} \mathrm{W}, 16.10 .2004$ (YMM).

CAUCASIAN RECORDS. Abkhzia, SE Azerbaijan [Marusik et al., 2005b].

COMMENTS. This species was well described by Marusik et al. [2005b]. Judging from the shape of the male palp it seems that the species does not belong to the genus Yaginumena (type species Y. castrata (Bösenberg et Strand, 1906)).

DISTRIBUTION. This species is known from the Caucasus and Japan only [Marusik et al., 2005b]. 


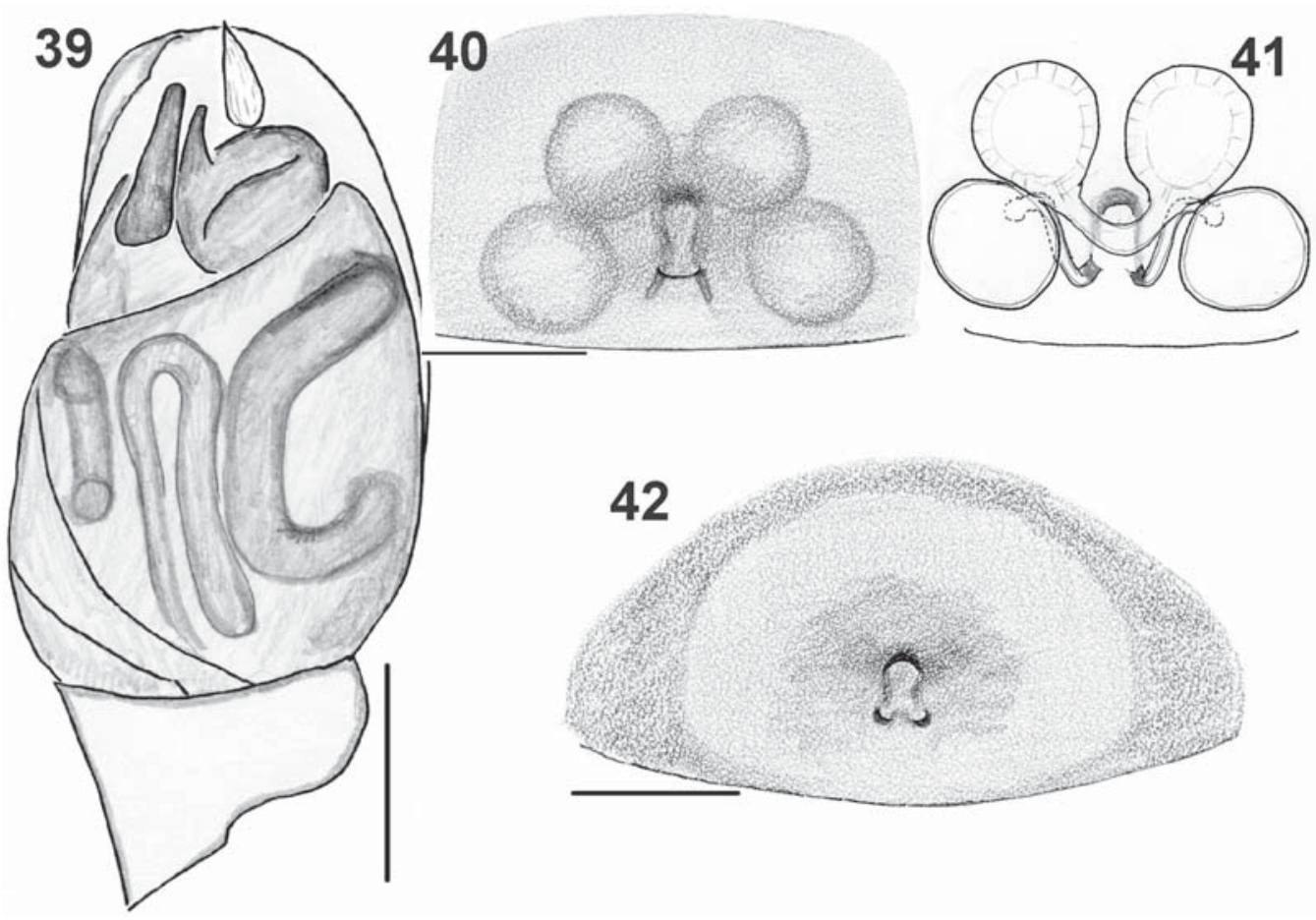

Figs 39-42. Male palp and epigyne of Yaginumena maculosa after Marusik et al. [2005b]: 39 - male palp, ventral; 40, 42 — epigyne, ventral; 41 - epigyne, dorsal.

Рис. 39-42. Пальпа самца и эпигина Yaginumena maculosa, по: Marusik et al. [2005b]: 39 — пальпа самца, вентрально; 40, 42 эпигина, вентрально; 41 - эпигина, дорсально.

ACKNOWLEDGMENTS. We thank R.S. Dbar (Sukhum, Abkhazia) for logistic help and N.N. Yunakov (Magdeburg, Germany) for help with collecting in expeditions in Abkhazia, and B. Knoflach (Innsbruck, Austria) for consultations dealing with the terminology of copulatory organs in Lasaeola. We are very grateful to E.F. Huseynov (Baku, Azerbaijan) who provided us with material used in this study. We sincerely thank Seppo Koponen (Turku, Finland) who arranged our stay in Turku and provided lab equipment. English of the final draft was kindly checked and edited by David Penney. This work was supported in part by the Karadag Nature Reserve and the Russian Foundation for Basic Research (grants \#\# 11-0401716 and 12-04-01548).

\section{References}

Dunin P.M. 1989. [Fauna and altitudinal distribution of spiders (Arachnida, Aranei) of the Azerbaijan part of the southern macroslope of the Caucasus Major] // Fauna i ecologia paukov i skorpionov. Arachnologicheski sbornik. Moscow. P.31-39 [in Russian].

Finch O.-D. 1999. Erstnachweis von Dipoena nigroreticulata (Simon, 1879) in Deutschland (Araneae, Theridiidae) // Arachnologische Mitt. H.18. S.66-70.

Fitzgerald B.M., Sirvid P.J. 2009. Notes on the genus Phycosoma Cambridge, 1879, senior synonym of Trigonobothrys Simon, 1889 (Theridiidae: Araneae) // Tuhinga. Vol.15. P.7-12.

Guseinov E.F. 2002. [Spider (Arachnida: Araneae) species new to fauna of the fauna of Caucasus] // IV Mezhdunarodnaya konferentsiya «Biologicheskoe raznoobrazie Kavkaza». Makhachkala. P.291-293 [in Russian].

Helsdingen P.J. 2010. Fauna Europaea: Araneae. Fauna Europaea version 2.2. http://www.faunaeur.org
Knoflach B., Pfaller K. 2004. Kugelspinnen - eine Einführung (Araneae, Theridiidae) // Thaler K. (ed.). Diversität und Biologie von Webspinnen, Skorpionen und anderen Spinnentieren. Denisia. Bd.12. P.111-160.

Marusik Yu.M., Guseinov E.F., Aliev H.A. 2005a. Spiders (Arachnida, Aranei) of Azerbaijan 4. Fauna of Nakhchivan // Arthropoda Selecta. Vol.13. No.3. P.135-149.

Marusik Yu.M., Guseinov E.F., Koponen S., Yoshida H. 2005b. A new case of Caucasus-Far East disjunctive range in spiders (Araneae) // Acta Arachnologica. Vol.53. No.2. P.125-129.

Miller F. 1967. Studien über die Kopulationsorgane der Spinnengattung Zelotes, Micaria, Robertus und Dipoena nebst Beschreibung einiger neuen oder unvollkommen bekannten Spinnenarten // Prirodov. Pr. Cesk. Akad. Ved (N.S.). Vol.1. P.251298.

Mkheidze T.S. 1997. [Spiders of Georgia: systematics, ecology, zoogeographic review]. Tbilisi Univ. 390 pp. [in Georgian].

Otto S., Tramp S. 2011. Caucasian Spiders - A faunistic database on the spiders of the Caucasus (Version 2.0 Beta). http://db.caucasusspiders.info/Area/152 (Accessed July 2011).

Paquin P., Dupérré N. 2003. Guide d'identification des araignées de Québec // Fabreries. Suppl.11. P.1-251.

Platnick N.I. 2012. The world spider catalog, version 13. American Museum of Natural History. http://research.amnh.org/entomology/spiders/catalog/index.html (Accessed August 22, 2012)

Ponomarev A.V., Mikhailov K.G. 2007. [Additions to the spider fauna (Aranei) of the Russian Caucasus] // Lebedeva N.V. (ed.). Bioraznoobraziye i transformatsiya gornykh ekosistem Kavkaza. Trudy Yuzhnogo nauchnogo tsentra RAN. Rostovna-Donu. YuNTs RAN Press. Vol.3. P.130-151 [in Russian].

Roberts M.J. 1985. The spiders of Great Britain and Ireland. Volume 1: Atypidae to Theridiosomatidae. Colchester: Harley Books. 229 pp.

Roberts M.J. 1995. Collins Field Guide: Spiders of Britain \& Northern Europe. London: HarperCollins. 383 pp. 
Roberts M.J. 1998. Spinnengids. Baarn: Tirion. 397 pp.

Wiehle H. 1937. Spinnentiere oder Arachnoidea. VIII. Theridiidae oder Haubennetzspinnen (Kugelspinnen) // Die Tierwelt Deutschlands. Jena. Bd.33. Hf.26. S.119-222.

Wunderlich J. 1988. Die Fossilen Spinnen im Dominikanischen Bernstein. Straubenhardt, West Germany. 378 S.

Wunderlich J. 2008. On extant and fossil (Eocene) European combfooted spiders (Araneae: Theridiidae), with notes on their subfamilies, and with descriptions of new taxa // Beitr. Araneol. Bd.5. P.140-469.
Yoshida H., Ono H. 2000. Spiders of the genus Dipoena (Araneae, Theridiidae) from Japan // Bull. natn. Sci. Mus. Tokyo. Ser.A. Vol.26. P.125-158.

Yoshida H. 2003. [The spider family Theridiidae (Arachnida: Araneae) from Japan]. Arachnological Society of Japan. 224 pp. [in Japanese].

Yoshida H. 2009. [Theridiidae] // The Spiders of Japan with keys to the families and genera and illustrations of the species. Kanagawa: Tokai Univ. Press. P.356-393 [in Japanese].

Responsible editor S. Koponen 